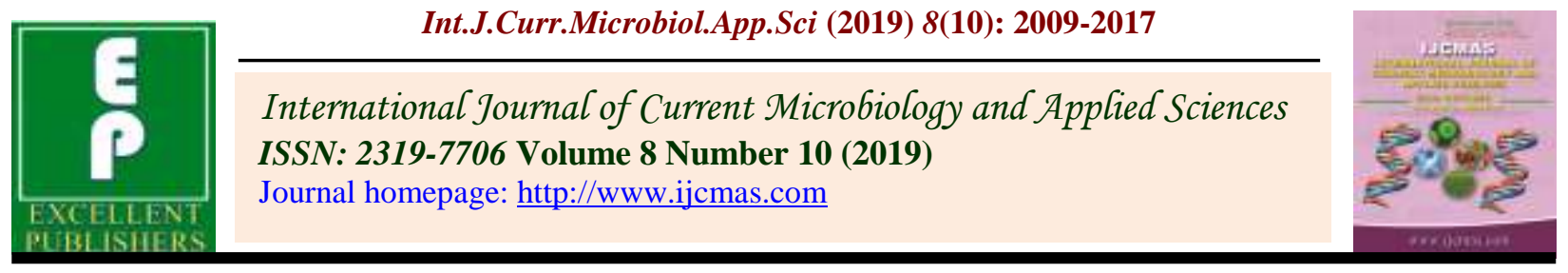

Original Research Article

https://doi.org/10.20546/ijcmas.2019.810.234

\title{
In vitro Response of Promising Sugarcane Varieties for Salinity Tolerance through Callus Culture
}

\author{
V. Patel Devangi* , S.C.Mali², J. Udutha ${ }^{2}$ and Patel Nilpa ${ }^{3}$ \\ ${ }^{1}$ Department of Genetics and Plant Breeding, ${ }^{2}$ Main Sugarcane Sugarcane Research, \\ ${ }^{3}$ Department of Plant Molecular Biology and Biotechnology, \\ Navsari Agricultural University, Navsari, India
}

*Corresponding author

\section{A B S T R A C T}

\begin{tabular}{|l|}
\hline Ke y w o r d s \\
$\begin{array}{l}\text { Sugarcane, Salinity, } \\
\text { Tissue culture, } \text { in } \\
\text { vitro, Somaclonal } \\
\text { variation }\end{array}$ \\
\hline Article Info \\
\hline $\begin{array}{l}\text { Accepted: } \\
15 \text { September } 2019 \\
\text { Available Online: } \\
10 \text { October } 2019\end{array}$ \\
\hline
\end{tabular}

Present investigation was carried out to screen two promising sugarcane varieties CoN 13073 and CoN 09072 for salinity tolerance through callus culture. Various physiological and morphological parameters was studied, maximum shoot length was observed at $2.0 \%$ $\mathrm{NaCl}$ concentration treated to callus at 65 days of culturing in variety CoN 13073, similar trend was observed for root length and leaf number per plant in variety CoN 13073 at 2.0 $\% \mathrm{NaCl}$ concentration.. Very little differences observed in shoot: root ratio in variety CoN 09072, while there was much difference was observed in shoot : root ratio at various levels of $\mathrm{NaCl}$ in variety $\mathrm{CoN} 13073 \mathrm{~S}$. Leaf area, chlorophyll content and $\mathrm{Na}: \mathrm{K}$ ratio were decreased with increased the concentration of $\mathrm{NaCl}$ in both the varieties Shoot regenerated under high concentrations of $\mathrm{NaCl}$ shown maximum chlorophyll content and leaf area in both the varieties. In comparatives studies, CoN 13073 responded positively to higher concentrations for all the characters studied.

\section{Introduction}

Sugarcane industry is the second largest agrobased industry in India. It is grown under varied agro-climatic conditions, hence it faces various biotic and abiotic stresses that impact the productivity in significant way. Salinity is one of the major abiotic stress which greatly affects the sugarcane productivity and recovery. The soils with electrical conductivity (EC) less than 4 dsm-1are generally considered as salt-free, whereas soil with EC range between 4-8 dsm-1are generally considered as salty soil. Salinity is a significant factor that affects crop production and agricultural sustainability worldwide, since about $10 \%$ of the land surface and $50 \%$ of all irrigated land in the world are prone to salinity (Flowers et al., 2010). Salt stress affects several aspects of plant physiology by its osmotic and ionic components (Munns and Tester, 2008).

Sugarcane is a typical glycophyte and hence exhibits stunted growth or no growth under salinity, with its yield falling to $50 \%$ or less 
than its true potential (Subbarao and Shaw, 1985). Salinity in the root zone of sugarcane decreases sucrose content, through its effect on both biomass and juice quality (Lingle and Wiegand, 1996). Salinity may interfere with sugar production in two major ways, first by affecting growth rate and yield of the cane secondly by affecting the sucrose content of the stalk (Rozeff, 1995). In any crop improvement program prime importance is given to yield and quality parameters. Development of high yields and high sugar recovery genotypes in sugarcane through conventional breeding program is the time consuming. So, In vitro screening and evaluation of sugarcane genotypes for salinity tolerance is a substitute improvement program. Sugarcane is an important cash crop of South Gujarat region. Gujarat has 1600 km costal area which is largest area among all states in India, so some area of sugarcane cultivation affected by salt accumulated through sea water as well as improper irrigation practices and sugarcane - paddy crop rotation is very common in the state which leads to excessive use of water causing soil salinity. This situation decreased the production as well as area of sugarcane cultivation in South Gujarat region. So, there is a need to develop resistant/tolerant somaclones of sugarcane varieties. So, present investigation was carried out to screen two promising sugarcane varieties CoN 13073 and CoN 09072 for salinity tolerance through callus culture at sugarcane tissue culture laboratories, Main Sugarcane Research Station, Navsari Agricultural University, Navsari. Various physiological and morphological parameters was studied.

\section{Materials and Methods}

The commercial cultivars of sugarcane $\mathrm{CoN}$ 13073 and CoN 09072 grown in Gujarat were used as the source of explants in this experiment. The explants were obtained from
Main Sugarcane Research Station, Navsari Agricultural University, Navsari. The direct leaf whorl and meristem of sugarcane were used as explants and these explants were true to type, visually healthy and disease free. Disease-free and actively growing cane tops were selected from five months old sugarcane crop as an explant. Cane tops with the growing apices were cut approximately $10 \mathrm{~cm}$ long and washed thoroughly in running tap water for 30 minutes. Outer sheaths of cane tops were removed by wiping the sheath with rectified spirit. The shoots were then washed with soap water for about five to six minutes in a sterile 1 liter conical flask followed by cleaning the materials with distilled water. The shoots were rinsed in 5 per cent sodium hypochlorite for 10 minutes.

Then shoots were thoroughly rinsed in 70 per cent ethanol for 30 seconds followed by sterilize double distilled water for four to five times till ethanol was completely washed out from the surface of material. Surface sterilization was performed by using 0.1 per cent mercuric chloride solution. Shoots were shaken vigorously for 5 minutes. Then the container was taken to a laminar clean air station. They were rinsed three to four times with sterile double distilled water to remove all traces of chemicals. The isolation of shoot apex was done by carefully removing the two to three outer whorls of the developing leaves with the help of a sterile sharp blade. The second innermost whorls of developing leave cut in to small pieces of approximately one centimeter length with the help of a sterile sharp blade and utilized as explant for callus induction on MS medium supplemented with different concentrations of 2,4-D $(0,1,2,3,4$, and $5 \mathrm{mg} / \mathrm{l}$ ) in different treatments along with $2 \mathrm{mg} / \mathrm{l} \mathrm{NAA}$ as constant for callus induction Good quality callus generated from leaf whorl and meristem was selected for further experimentation to impose different levels of $\mathrm{NaCl}$ concentration and to check the response 
to salinity tolerance on the basis of in vitro evaluation procedure in both the varieties. In regeneration medium, NAA $2 \mathrm{mg} / \mathrm{l}+\mathrm{BAP}$ $1 \mathrm{mg} / \mathrm{l} \mathrm{kept} \mathrm{constant} \mathrm{in} \mathrm{all} \mathrm{the} \mathrm{treatments.}$

Transfer the regenerated shoots on rooting medium i.e., $\mathrm{MS}+\mathrm{NAA}(2 \mathrm{mg} / \mathrm{l})+\mathrm{BAP}$ $(1 \mathrm{mg} / \mathrm{l})+$ different concentration of $\mathrm{NaCl}$. Incubate the culture either in the incubator or growth room maintained at temperature $25 \pm$ $2^{0} \mathrm{C}$, with florescent light (3000-5000 Lux), 16 hrs light/ $8 \mathrm{hrs}$ dark regimes and possessing good relative humidity $(60-80 \%)$. The best and healthy plantlets were selected as tolerant somaclonal variants for the next evaluations. After successful regeneration of multiple shoots at different levels of $\mathrm{NaCl}$ concentration in MS medium. The plantlets were shifted to polythene bags with sand + soil + compost (1:1:1) at primary hardening. Polythene bags were irrigated at alternate days and the irrigation water was incorporate with different levels of $\mathrm{NaCl}$ concentration to evaluate salinity tolerance at primary hardening considering morphological and physiological parameters.

\section{Observation recorded during experiment}

Length of regenerated shoots from callus developed on different treatments medium, measured in centimeter after 25 days for fourth subculturing and length of shoot was measured from collar region to the tip of top most leaf. Root length of in vitro plantlets was measured in centimetre. These observations were recorded at the 30 day after inoculation on rooting media. The length of the root was measured from collar region down to tip of the longest root. Plant height $(\mathrm{cm})$ was recorded under primary hardening after 25 days of planting. Chlorophyll content index was recorded with help of chlorophyll content meter (CCM - 200 plus manufactured by Apogee Instrument). It measures the absorbance of both wavelengths and calculates a Chlorophyll Concentration Index (CCI) value that was proportional to the amount of chlorophyll in the sample of each treatment. The leaves from plants selected from each treatment were used for the estimation of leaf area after 25 days of planting. Leaf area was measured by leaf area meter (Model LI3000, LI-COR, USA) and expressed as $\mathrm{cm} 2$. Total number of green leaves on the plant from each treatment were counted at 60 days after planting and recorded. Shoot root ratio was estimated by dry weight basis. The potassium and sodium contents were estimated by flame photometer (Jenway PFP 7, ELE Instrument Co. Ud.) method and expressed as ratio on the basis of dry weight. Survival per cent was calculated on the basis of number of plantlets survived from the total number at each treatment combination.

\section{Statistical analysis}

The data generated from the various in vitro experiments were subjected to statistical analysis in Completely Randomized Design (CRD).

\section{Results and Discussion}

\section{Shoot length (cm)}

In variety CoN 13073 maximum shoot length was observed in MS medium supplemented with $2 \mathrm{mg} / \mathrm{l} \mathrm{NAA}+1 \mathrm{mg} / \mathrm{l} \mathrm{BAP}+2.0 \% \mathrm{NaCl}$ in treatment $\mathrm{T}_{5}(5.8 \mathrm{~cm})$, followed by $\mathrm{MS}$ medium without $\mathrm{NaCl}$ in treatment $\mathrm{T}_{1}(5.2$ $\mathrm{cm})$ and treatment $\mathrm{T}_{2}, \mathrm{MS}+0.5 \% \mathrm{NaCl}(4.8$ $\mathrm{cm})$. Whereas minimum shoot length was observed in treatment $\mathrm{T}_{6} \mathrm{MS}$ supplemented with $2.5 \% \mathrm{NaCl}(3.5 \mathrm{~cm})$.

In variety CoN 09072 maximum shoot length was observed in MS medium supplemented with $0.5 \% \mathrm{NaCl}$ in treatment $\mathrm{T}_{2}(4.8 \mathrm{~cm})$, followed by $\mathrm{MS}+1.0 \% \mathrm{NaCl}$ in treatment $\mathrm{T}_{3}$ $(4.6 \mathrm{~cm})$ and $\mathrm{MS}+1.5 \% \mathrm{NaCl}$ in treatment $\mathrm{T}_{4}$ 
and without $\mathrm{NaCl}$ in treatment $\mathrm{T}_{1}(4.4 \mathrm{~cm})$. Whereas minimum shoot length was observed in MS medium supplemented with $2.5 \% \mathrm{NaCl}$ concentration in treatment $\mathrm{T}_{6}(3.4 \mathrm{~cm})$. MS medium without $\mathrm{NaCl}$ concentration registered above to average shoot length.

The plantlets regenerated from callus supplemented with MS medium + different levels of $\mathrm{NaCl}$ showed significant differences in shoot length. Among both the varieties $\mathrm{CoN}$ 13073 exhibited maximum shoot length at higher $\mathrm{NaCl}$ concentration compared to variety CoN 09072. Very little differences in shoot length were observed in variety $\mathrm{CoN}$ 09072. The MS medium with $2 \% \mathrm{NaCl}$ showed maximum shoot length in variety $\mathrm{CoN}$ 13073, followed by MS medium without $\mathrm{NaCl}$. Whereas decline in shoot length was observed with the increase in $\mathrm{NaCl}$ concentration in variety $\mathrm{CoN}$ 09072. At higher concentration of $\mathrm{NaCl} 2.5 \%$ both the varieties responded negatively and resulted reduced shoot length. These results are agreement with Wahid and Ghazanfar (2006) and Ather et al., (2009). The minimum shoot length was observed in plantlets treated with $2.5 \% \mathrm{NaCl}$. The saline solution may be at a higher water potential like sea water. Plants challenged by this magnitude of water potential developed through medium, so the leaf is unable to meet the transpirational demands. Somaclonal variation appears due to various biological phenomena like, chromosomal aberration, cytoplasmic changes, mitotic crossing over and genetic rearrangement. Variation might have been created during callus formation. The same was reflected in one of the sub culture where surprisingly more shoot and root length was observed even under higher $\mathrm{NaCl}$ concentration. The present finding is in accordance with Shomeili et al., (2011).

\section{Root length (cm)}

The multiple shoots developed from regeneration media were shifted to rooting media, $1 / 2 \mathrm{MS}$ medium was supplemented with NAA $2 \mathrm{mg} / \mathrm{l}+$ IBA $2 \mathrm{mg} / \mathrm{l} \mathrm{kept} \mathrm{constant} \mathrm{and}$ different $\mathrm{NaCl}$ concentrations were imposed to the culture as per treatment combination.

In variety CoN 13073 maximum root length was observed in treatment $\mathrm{T}_{5}(4.4 \mathrm{~cm})$, where $1 / 2$ MS medium was supplemented with $2.0 \%$ $\mathrm{NaCl}$ concentration along with NAA and IBA standard, followed by $1 / 2 \mathrm{MS}+\mathrm{NaCl} 1.0 \%$ in treatment $\mathrm{T}_{3}(4.2 \mathrm{~cm})$. Moderate root length was observed in $1 / 2 \mathrm{MS}$ medium without $\mathrm{NaCl}$ whereas $1 / 2$ MS medium supplemented with $2.5 \% \mathrm{NaCl}$ concentration in treatment $\mathrm{T}_{6}(2.2$ $\mathrm{cm})$ registered minimum root length.

The response of both the varieties to different $\mathrm{NaCl}$ concentration was highly differential. Variety CoN 13073 responded positively to higher $\mathrm{NaCl}$ concentration up to $2 \%$ for root length. Whereas variety CoN 09072 responded positively to $\mathrm{NaCl}$ concentration up to $1.0 \%$ then after there is reduction in root length was observed. In both the varieties minimum root length was observed when plantlets developed from callus supplemented with $2.5 \% \mathrm{NaCl}$. Among both the varieties $\mathrm{CoN} 13073$ exhibited moderate in root length to higher $\mathrm{NaCl}$ concentration. These results are in agreement with Akhtar et al., (2003) and Shomeili et al., (2011). According to Mathur et al., (2008) root growth is the prime parameter that affected by salinity condition. At high saline condition rapid inhibition of root growth was observed and hence reduction in uptake of water and essential nutrients can be seen at field condition.

\section{Plant height (cm)}

Maximum plant height was observed in treatment $\mathrm{T}_{5}$ (21.4) where rooting mixture was supplemented with $2.0 \% \mathrm{NaCl}$ concentration in variety $\mathrm{CoN} 13073$ followed by treatment T3 $(20.6 \mathrm{~cm})$. While minimum plant height was registered in rooting mixture supplemented with $2.5 \% \mathrm{NaCl}$ concentration 
in treatment $\mathrm{T}_{6}(10.6 \mathrm{~cm})$. Whereas average plant height was observed in rooting mixture without $\mathrm{NaCl}$ concentration in treatment $\mathrm{T} 1$ $(16.5 \mathrm{~cm})$.

In variety $\mathrm{CoN}$ 09072, rooting mixture without $\mathrm{NaCl}$ concentration registered maximum plant height in treatment $\mathrm{T}_{1}$ (14.4 $\mathrm{cm})$ followed by rooting mixture with $2.0 \%$ $\mathrm{NaCl}$ concentration in treatment $\mathrm{T}_{5}(13.5 \mathrm{~cm})$ and rooting mixture with $0.5 \% \mathrm{NaCl}$ concentration in treatment $\mathrm{T}_{2}(12.6 \mathrm{~cm})$. Whereas minimum plant height was recorded in rooting mixture with $2.5 \% \mathrm{NaCl}$ concentration in treatment T6 $(8.2 \mathrm{~cm})$.

Both the varieties responded poorly to higher $\mathrm{NaCl}$ concentration at primary hardening level. Similar results were noticed by Shomeili et at., (2011). Among both the varieties effect of salinity in the plant height was not significant in CoN 13073 that indicate at high sodium levels up-taking of nutrients from the rooting mixture were not inhibited and water potential retained at cellular level at saline condition.

\section{Chlorophyll content index}

The plantlets developed from callus culture in MS medium supplemented with different $\mathrm{NaCl}$ (0 to $2.5 \%$ ) concentration registered maximum chlorophyll content index in treatment $T_{2}(5.40)$, followed by treatment $T_{1}$ (5.27) and $\mathrm{T}_{3}$ treatment (4.87). While plantlets registered from callus culture and rooting mixture supplemented with $\mathrm{NaCl} 2.5 \%$ concentration resulted minimum chlorophyll content index in treatment $\mathrm{T}_{6}(3.70)$ in variety CoN 13073.

In variety CoN 09072 maximum chlorophyll content index was observed in plantlets developed from rooting mixture without $\mathrm{NaCl}$ (\%) and registered maximum chlorophyll content (4.86) followed by treatments $\mathrm{T}_{2}$
(4.54) and $\mathrm{T}_{3}$ (4.27). while minimum chlorophyll content index was observed in the plantlets developed from the rooting mixture with $2.5 \% \mathrm{NaCl}$ in treatment $\mathrm{T}_{6}(3.67)$.

The plantlets regenerated from callus culture were imposed to different $\mathrm{NaCl}$ concentration in rooting mixture and observed low differences among chlorophyll content in both varieties. In variety $\mathrm{CoN} 09072$ control showed maximum chlorophyll content. Increased in the level of $\mathrm{NaCl}$ the chlorophyll content was decreased gradually. These results are agreement with Wahid and Ghazanfar (2005) and Shomeili et al., (2011). The minimum chlorophyll content was observed in plantlets treated with $2.5 \% \mathrm{NaCl}$. Chlorophyll content can be used as a sensitive indicator of the cellular metabolic state, thus its decrease signifies toxicity in tissues due to accumulation of ions.

\section{Leaf area $\left(\mathrm{cm}^{2} /\right.$ plant $)$}

In variety $\mathrm{CoN} 13073$, rooting mixture without $\mathrm{NaCl}$ registered maximum leaf area $\mathrm{T}_{1}$ $\left(41.6 \mathrm{~cm}^{2}\right)$, followed by treatment with $\mathrm{NaCl}$ concentration $0.5 \%$ in treatment $\mathrm{T}_{2}\left(40.7 \mathrm{~cm}^{2}\right)$ and with $2.0 \% \mathrm{NaCl}$ concentration in treatment $\mathrm{T}_{5}\left(40.4 \mathrm{~cm}^{2}\right)$. Minimum leaf area was registered in treatment with $2.5 \% \mathrm{NaCl}$ concentration $\mathrm{T}_{6}\left(32.6 \mathrm{~cm}^{2}\right)$.

In variety $\mathrm{CoN} 09072$ maximum leaf area was registered in rooting mixture without $\mathrm{NaCl}$ concentration in treatment $\mathrm{T}_{1}\left(40.4 \mathrm{~cm}^{2}\right)$, followed by $0.5 \% \mathrm{NaCl}$ concentration in treatment $\mathrm{T}_{2}\left(38.5 \mathrm{~cm}^{2}\right)$ and with $2.0 \% \mathrm{NaCl}$ concentration in treatment $\mathrm{T}_{5}\left(36.4 \mathrm{~cm}^{2}\right)$. Whereas minimum leaf area was registered with $2.5 \% \mathrm{NaCl}$ concentration in treatment $\mathrm{T}_{6}$ $\left(32.3 \mathrm{~cm}^{2}\right)$.

High leaf area was observed in control condition $(0 \% \mathrm{NaCl})$ while, minimum leaf area was observed where plantlets treated with 
$2.5 \% \mathrm{NaCl}$ in both the varieties. Similar results were observed by Wahid (2004), Shomeili et al., (2011) and Reena et al., (2017).

\section{Leaf number per plant}

Rooting mixture supplemented with $2.0 \%$ $\mathrm{NaCl}$ registered maximum number of leaves in treatment $\mathrm{T}_{5}$ (3.4), followed by the rooting mixture supplemented with $0.5 \% \mathrm{NaCl}$ in treatment $\mathrm{T}_{2}$ (3.0) and rooting mixture with $1.5 \% \mathrm{NaCl}$ in treatment $\mathrm{T}_{4}(2.8)$ in variety CoN 13073. Whereas moderate leaf number was observed in rooting mixture without $\mathrm{NaCl}$ and minimum leaf number was registered in rooting mixture supplemented with $2.5 \%$ $\mathrm{NaCl}$ in treatment $\mathrm{T}_{6}(2.0)$.

In variety CoN 09072, rooting mixture supplemented with $0.5 \% \mathrm{NaCl}$ registered maximum number of leaves in treatment $\mathrm{T}_{2}$ (2.6) followed by rooting mixture with $2.0 \%$ $\mathrm{NaCl}$ in treatment $\mathrm{T}_{5}(2.4)$ and treatment $\mathrm{T}_{3}$ (2.2). Whereas rooting mixture with $2.5 \%$ $\mathrm{NaCl}$ registered minimum number of leaves in treatment $\mathrm{T}_{6}(1.5)$.

The plantlets regenerated from MS medium supplemented with different $\mathrm{NaCl}$ concentration showed narrow differences among different treatment for leaf number (Table 1) in variety $\mathrm{CoN}$ 09072. Whereas plantlets regenerated from MS medium supplemented with different $\mathrm{NaCl}$ concentration showed wide difference among different treatment for leaf number in variety $\mathrm{CoN}$ 13073. Higher numbers of leaves were observed in $2.0 \% \mathrm{NaCl}$ while minimum leaf number observed in $2.5 \% \mathrm{NaCl}$ in $\mathrm{CoN}$ 13073. Whereas higher leaf number were observed in control condition $(0 \% \mathrm{NaCl})$ while minimum leaf number were observed when plantlets were treated with $2.5 \% \mathrm{NaCl}$ in $\mathrm{CoN}$ 09072. A similar result was observed by Shomeili et al., (2011) as the increase in concentration of $\mathrm{NaCl}$ leaf number decreased.

\section{Shoot : root ratio}

In variety CoN 13073 maximum shoot : root ratio was observed in rooting mixture with 0.5 $\% \mathrm{NaCl}$ concentration in treatment $\mathrm{T}_{2}$ (2.4), followed by rooting mixture with $1.5 \%$

$\mathrm{NaCl}$ concentration in treatment $\mathrm{T}_{4}$ (2.2) and rooting mixture with $1.0 \% \quad \mathrm{NaCl}$ concentration in treatment $\mathrm{T}_{3}(2.0)$. Whereas minimum shoot : root ratio was observed in treatment $\mathrm{T}_{6} \quad(1.3)$ with $2.5 \% \quad \mathrm{NaCl}$ concentration.

In variety $\mathrm{CoN} 09072$ maximum shoot : root ratio was observed in rooting mixture with 0.5 $\% \mathrm{NaCl}$ concentration in treatment $\mathrm{T}_{2}$ (1.8), followed by rooting mixture with $1.5 \% \mathrm{NaCl}$ concentration in treatment in treatment $\mathrm{T}_{4}$ (1.6). Whereas minimum shoot root ratio was observed in treatment $\mathrm{T}_{5}(1.2)$ with $2.0 \%$ $\mathrm{NaCl}$ concentration.

The plantlets regenerated from callus culture taken to primary hardening and imposed with $\mathrm{NaCl}$ levels in rooting mixture exposed very little differences in shoot root ratio in variety CoN 09072. While there was much differences was observed in shoot : root ratio at various levels of $\mathrm{NaCl}$ in variety $\mathrm{CoN}$ 13073.

Lower concentration of $\mathrm{NaCl} 0.5 \%$ resulted higher shoot:root ratio. Whereas higher concentration of $\mathrm{NaCl} 2.5 \%$ resulted lower shoot:root ratio in both the varieties.

In the comparative study, variety CoN 13073 showed superior for shoot: root ratio at higher concentration of $\mathrm{NaCl}$, at primary hardening. The increase in value of the shoot:root dry weight ratio at high $\mathrm{NaCl}$ indicates that root was positively affected by salinity than shoots.

These results are in agreement with Akhtar et al., (2003) and Shomeili et al., (2011). 
Table.1 Response of sugarcane varieties CoN 13073 and CoN 09072 to salt stress

\begin{tabular}{|c|c|c|c|c|c|c|c|c|c|c|c|c|c|c|c|c|c|c|}
\hline \multirow[t]{2}{*}{ S.No } & \multicolumn{2}{|c|}{ Shoot length $(\mathrm{cm})$} & \multicolumn{2}{|c|}{ Root length (cm) } & \multicolumn{2}{|c|}{ Plant height (cm) } & \multicolumn{2}{|c|}{$\begin{array}{l}\text { Chlorophyll } \\
\text { content index }\end{array}$} & \multicolumn{2}{|c|}{$\begin{array}{l}\text { Leaf area } \\
\left(\mathrm{cm}^{2} / \text { plant }\right)\end{array}$} & \multicolumn{2}{|c|}{$\begin{array}{c}\text { Leaf number per } \\
\text { plant }\end{array}$} & \multicolumn{2}{|c|}{ Shoot : root ratio } & \multicolumn{2}{|c|}{$\mathrm{Na}: \mathrm{K}$ ratio } & \multicolumn{2}{|c|}{ Survival per cent } \\
\hline & \begin{tabular}{|c|} 
Variety \\
13073
\end{tabular} & $\begin{array}{l}\text { Variety } \\
09072\end{array}$ & $\begin{array}{c}\text { Variety } \\
13073\end{array}$ & $\begin{array}{l}\text { Variety } \\
09072\end{array}$ & $\begin{array}{c}\text { Variety } \\
13073\end{array}$ & $\begin{array}{l}\text { Variety } \\
09072\end{array}$ & $\begin{array}{c}\text { Variety } \\
13073\end{array}$ & $\begin{array}{l}\text { Variety } \\
09072\end{array}$ & $\begin{array}{c}\text { Variety } \\
13073\end{array}$ & $\begin{array}{c}\text { Variety } \\
13073\end{array}$ & $\begin{array}{c}\text { Variety } \\
13073\end{array}$ & $\begin{array}{l}\text { Variety } \\
09072\end{array}$ & $\begin{array}{l}\text { Variety } \\
13073\end{array}$ & $\begin{array}{l}\text { Variety } \\
09072\end{array}$ & $\begin{array}{l}\text { Variety } \\
13073\end{array}$ & $\begin{array}{l}\text { Variety } \\
09072\end{array}$ & $\begin{array}{c}\text { Variety } \\
13073\end{array}$ & $\begin{array}{c}\text { Variety } \\
09072\end{array}$ \\
\hline$T_{1}$ & 5.20 & 4.40 & 2.60 & 3.00 & 16.50 & 14.40 & 5.27 & 4.86 & 41.60 & 40.40 & 2.80 & 2.00 & 1.80 & 1.41 & 0.86 & 0.78 & 87.50 & 70.40 \\
\hline $\mathbf{T}_{2}$ & 4.80 & 4.80 & 3.20 & 3.20 & 19.40 & 12.60 & 5.40 & 4.54 & 40.70 & 38.50 & 3.00 & 2.60 & 2.40 & 1.80 & 0.80 & 0.84 & 80.60 & 64.60 \\
\hline $\mathbf{T}_{3}$ & 4.20 & 4.60 & 4.20 & 2.80 & 20.60 & 10.50 & 4.87 & 4.27 & 34.30 & 36.10 & 2.40 & 2.20 & 2.00 & 1.40 & 0.76 & 0.80 & 72.30 & $\mathbf{5 8 . 5 0}$ \\
\hline $\mathbf{T}_{4}$ & 4.40 & 4.40 & 3.60 & 2.40 & 15.70 & 10.40 & 4.62 & 4.14 & 36.50 & 34.50 & 2.80 & 2.00 & 2.20 & 1.60 & 0.82 & 0.68 & 64.10 & 54.43 \\
\hline $\mathbf{T}_{5}$ & 5.80 & 4.00 & 4.40 & 2.10 & 21.40 & 13.50 & 4.20 & 3.86 & 40.40 & 36.40 & 3.40 & 2.40 & 1.80 & 1.20 & 0.84 & 0.74 & 84.60 & 50.60 \\
\hline $\mathbf{T}_{6}$ & 3.50 & 3.40 & 2.20 & 1.80 & 10.60 & 8.20 & 3.70 & 3.67 & 32.60 & 32.30 & 2.00 & 1.50 & 1.30 & 1.40 & 0.62 & 0.70 & 50.40 & 36.20 \\
\hline SEm & 0.12 & 0.12 & 0.10 & 0.01 & 0.44 & 0.21 & 0.01 & 0.01 & 0.45 & 0.56 & 0.01 & 0.02 & 0.01 & 0.01 & 0.01 & 0.01 & 0.57 & 0.58 \\
\hline CV & 0.37 & 0.37 & 0.33 & 0.05 & 1.36 & 0.67 & 0.05 & 0.04 & 1.39 & 1.72 & 0.04 & 0.06 & 0.05 & 0.04 & 0.05 & 0.05 & 1.75 & 1.79 \\
\hline CD & 4.47 & 4.87 & 5.55 & 1.16 & 4.41 & 3.26 & 0.69 & 0.59 & 2.08 & 2.67 & 0.95 & 1.83 & 1.80 & 1.88 & 4.17 & 4.17 & 1.34 & 1.80 \\
\hline
\end{tabular}

$\mathrm{T}_{1}=0 \% \mathrm{NaCl}, \mathrm{T}_{2}=0.5 \% \mathrm{NaCl}, \mathrm{T}_{3}=1.0 \% \mathrm{NaCl}, \mathrm{T}_{4}=1.5 \% \mathrm{NaCl}, \mathrm{T}_{5}=2.0 \% \mathrm{NaCl}, \mathrm{T}_{6}=2.5 \% \mathrm{NaCl}$ 


\section{Na : K ratio}

In variety CoN 13073 plantlets developed without $\mathrm{NaCl}$ in the rooting mixture registered maximum $\mathrm{Na}: \mathrm{K}$ ratio in treatment $\mathrm{T}_{1}$ (0.86) followed by plantlets developed from rooting mixture with $2.0 \% \mathrm{NaCl}$ concentration in treatment $\mathrm{T}_{5}(0.84)$ and plantlets developed from $1.5 \% \mathrm{NaCl}$ concentration in treatment $\mathrm{T}_{4}(0.82)$. Whereas minimum $\mathrm{Na}: \mathrm{K}$ ratio was observed in rooting mixture with $2.5 \% \mathrm{NaCl}$ concentration in treatment $\mathrm{T}_{6}(0.62)$.

In variety CoN 09072 plantlets developed from rooting mixture with $0.5 \% \mathrm{NaCl}$ registered maximum $\mathrm{Na}: \mathrm{K}$ ratio in treatment $\mathrm{T}_{2}$ (0.84) followed by rooting mixture with $1.0 \% \mathrm{NaCl}$ concentration in treatment $\mathrm{T}_{3}$ $(0.80)$ and rooting mixture without $\mathrm{NaCl}$ concentration in treatment $\mathrm{T}_{1}(0.78)$. Minimum $\mathrm{Na}: \mathrm{K}$ ratio was observed in rooting mixture with $1.5 \% \quad \mathrm{NaCl}$ concentration in treatment $\mathrm{T}_{4}(0.68)$.

The plantlets regenerated through callus culture were taken for primary hardening and in the rooting mixture different $\mathrm{NaCl}(0$ to 2.5 $\%)$ concentrations were imposed and observed much differences in $\mathrm{Na}: \mathrm{K}$ ratio among the treatments and among the varieties. Higher $\mathrm{Na}: \mathrm{K}$ ratio was observed in control condition $(0 \% \mathrm{NaCl})$ in $\mathrm{CoN} 13073$ while $(0.5 \% \mathrm{NaCl})$ in $\mathrm{CoN} 09072$. Whereas minimum $\mathrm{Na}: \mathrm{K}$ ratio was observed when plantlets treated with $2.5 \% \mathrm{NaCl}$ in both the varieties. These findings are in agreement with (Ahsarf, 2007; Karpeet al., (2012) and Reenaet al., (2017).

\section{Survival per cent}

Maximum survival per cent was registered in rooting mixture without $\mathrm{NaCl}$ concentration in treatment $\mathrm{T}_{1}(87.50 \%)$ followed by rooting mixture with $2.0 \% \mathrm{NaCl}$ concentration in treatment $\mathrm{T}_{5}(84.60)$ and rooting mixture with $0.5 \% \mathrm{NaCl}$ concentration in treatment $\mathrm{T}_{2}(80.60 \%)$ in variety CoN 13073 . Whereas minimum survival per cent was observed in rooting mixture supplemented with $2.5 \%$ $\mathrm{NaCl}$ concentration in treatment $\mathrm{T}_{6}(50.40 \%)$.

In variety $\mathrm{CoN}$ 09072, rooting mixture without $\mathrm{NaCl}$ registered maximum survival per cent in treatment $\mathrm{T}_{1}(70.40 \%)$ followed by rooting mixture with $0.5 \% \mathrm{NaCl}$ concentration in treatment $\mathrm{T}_{2}(64.60 \%)$ and rooting mixture with $1.0 \% \quad \mathrm{NaCl}$ concentration in treatment $\mathrm{T}_{3} \quad(58.50$ $\%)$. Whereas minimum survival per cent at primary hardening was observed in rooting mixture with $2.5 \% \mathrm{NaCl}$ in treatment $\mathrm{T}_{6}$ $(36.20 \%)$.

As the leaf provides the platform for photosynthesis. Leaf area indicates the strength of the source of energy of a crop. Photosynthesis and dry matter production of a plant is proportional to leaf number and shoot root ratio of a plant. Prolonged and high intensity abiotic stress leads to plasmolysis and retention of moisture content in plant body which isgoverned by physiological expression and genetic nature of a particular variety. Plantlets regenerated from callus culture were taken to primary hardening and different $\mathrm{NaCl}$ concentrations imposed in rooting mixture, observed that maximum survival per cent was recorded in rooting mixture without $\mathrm{NaCl}$ concentration in both the varieties. Increase in $\mathrm{NaCl}$ concentration resulted poor survival per cent at 25 days after primary hardening. Whereas at $2 \% \mathrm{NaCl}$ imposition optimum survival per cent was noticed in variety CoN 13073 that indicate particular variety is tolerant to salinity levels up to $2.0 \%$. Variety CoN 09072 responded poorly to high salinity levels at primary hardening that indicate Sensitivity of that particular variety to saline condition. Similar results at in vitro condition registered by Akhtar et al., (2011). 
Form the study it is concluded that in vitro selection can be used to identify salt tolerance clones in sugarcane and also to study physiological and biochemical parameters. Salt tolerance seems to be related to the efficiency of an individual varietal genetic constitution at cellular and molecular level to absorb, deposit and transport elements in both available and unavailable forms in response to salt stress. Clones derived from variety $\mathrm{CoN}$ 13073 showed higher tolerance towards $\mathrm{NaCl}$ up to $2.0 \%$ than variety $\mathrm{CoN}$ 09072. The study also suggests that in vitro cultured tissue or cell and plantlets can be useful as a system to screen for salinity stress in sugarcane. Overall, Variety CoN 13073 showed better performance in respect of all the characters in the study as compare to Variety CoN 09072.

\section{References}

Akhtar, S. A., Wahid, A., Akram, M. and Rasul, E. (2011). Some growth, photosynthetic and anatomical attributes of sugarcane genotypes under NaCI salinity. Int. J. Agri. Biol., 4: 439443.

Akhtar, S., Wahid, A. and Rasul, E. (2003). Emergence, growth and nutrient composition of sugarcane sprouts under $\mathrm{NaCl}$ salinity. Biol. Plant., 46: 113-116.

Ashraf, M., Rahmatullah, Kanwal, S., Tahir, M. A., Srwar, A. and Ali, L. (2007). Differential salt tolerance of sugarcane genotypes. Pak. $J$. Sci., 44(1): 85-88.

Ather, A., Khan, S., Rehman, A. and Nazir, M. (2009). Optimization of the protocols for callus Induction, regeneration and acclimatization of sugarcane cv. Thatta- 10 . Pak. J. Bot., 41(2): 815-820.
Flowers, T. J., Gala, H. K. and Bromham, L. (2010). Evolution of halophytes: multiple origins of salt tolerance in land plants. Funct. Plant Biol., 37: 604-612.

Karpe, A., Nikam, A. A., Chimote, K. P., Kalwade, S .B., Kawar, P. G., Babu, H., Devarumath, R. M. and Suprasanna, P. (2012). Differential responses to salinity stress of two varieties (CoC671 and Co 86032) of sugarcane (Saccharum officinarum L.). African J. Biotech, 11(37): 9028-9035.

Lingle, S. E. and Wiegand, C. L. (1996). Growth and yield responses of sugarcane to saline soil: II. Sucrose biochemistry in individual internodes. In: Proceedings of the Inter American Sugarcane Seminars, Miami, USA. 93-102.

Mathur, P. B., Vadez, V. and Sharma K. K. (2008). Transgenic approaches for abiotic stress tolerance in plants: retrospect and prospects. Plant Cell Rep., 27: 411-424.

Reena, D. P., Mali, S. C., Patel, A. I. and Patel P. K. (2017). In vitro response of promising sugarcane varieties for salinity tolerance through callus culture. International Journal of Chemical Studies, 5(4): 1180-1186.

Rozeff, N. (1995). Sugarcane and Salinity. A review paper Sugarcane, 5: 8-19.

Shomeili, M., Majid, N., Mosa, M. and Rajabi, M. (2011). Evaluation of sugarcane (Saccharum officinarum L.) somaclonal variants tolerance to salinity in vitro and in vivo cultures. African J. of Biotech, 10(46): 9337-9343.

Wahid, A. (2004). Analysis of toxic and osmotic effects of sodium chloride on leaf growth and economic yield of sugarcane. Botanical Bulletin of Academia Sinica, 45: 133-141.

Wahid, A. and Ghazanfar, A. (2006). Possible involvement of some secondary metabolites in salt tolerance of sugarcane. $J$. Pl. Physiol., 163: 723-730.

\section{How to cite this article:}

Patel Devangi, V., S.C. Mali, J. Udutha and Patel Nilpa. 2019. In vitro Response of Promising Sugarcane Varieties for Salinity Tolerance through Callus Culture. Int.J.Curr.Microbiol.App.Sci. 8(10): 2009-2017. doi: https://doi.org/10.20546/ijcmas.2019.810.234 